\title{
POLB wt Allele
}

National Cancer Institute

\section{Source}

National Cancer Institute. POLB wt Allele. NCI Thesaurus. Code C51340.

Human POLB wild-type allele is located in the vicinity of 8p11.2 and is approximately $33 \mathrm{~kb}$ in length. This allele, which encodes DNA polymerase beta protein, plays a role in DNA base excision repair which entails gap-filling DNA synthesis in a stepwise, distributive fashion. Defects in the POLB gene are associated with certain forms of cancer such as cervical and esophageal cancer. 